\title{
Expression of the cAMP Phosphodiesterase 7A1 Gene by Endoplasmic Reticulum Stress
}

\author{
Kisang $\mathrm{Kwon}^{1+}$, Young-Sook $\mathrm{Kwon}^{2+}$ and O-Yu Kwon ${ }^{1}$ * \\ ${ }^{1}$ Department of Anatomy, School of Medicine, Chungnam National University, Taejon 301-747, Korea \\ ${ }^{2}$ Department of Nursing, Joongbu University, Chungnam 312-702, Korea
}

Received December 21, 2011 /Revised February 8, 2012 / Accepted February 8, 2012

\begin{abstract}
This study demonstrated that upregulation of gene expression of endoplasmic reticulum (ER) stress chaperones (Bip, ERp29, calnexin, and PDI), ER stress sensors (PERK, ATF6, and Ire1), and cAMP phosphodiesterase 7A1 (cAMP PDE7A1) was induced by ER stresses in FRTL5 cells. While removing A23187 from the culture medium restored upregulation of cAMP PDE7A1 gene expression, removal of thapsigargin did not recover its expression. In addition, cAMP PDE7A1 gene expression was strongly inhibited by treatment with A23187 combined with thyroid stimulating hormone (TSH). The results are the first to show that ER stress induces cAMP PDE7A1 gene expression.
\end{abstract}

Key words : cAMP phosphodiesterase 7A1 (cAMP PDE7A1), endoplasmic reticulum (ER) stress, ER chaperone

\section{서 론}

세포는 외부의 급격한 환경변화에 대응하기 위하여 세포 내 자체 조절능력을 가진다. 세포의 정상적인 생리 상태를 혼 동시키는 것을 세포스트레스(cell stress)라고 하고, 그 중에서 도 소포체(endoplasmic reticulum, ER)에 크게 영향을 미치는 것을 소포체스트레스(ER stress)라고 한다[9]. 일반적으로 ER stress는 분비경로를 통해서 분비되어야할 단백질에 구조이상 이 생겨서 ER에 축적된다. 그 원인은 변이단백질의 발현과 비정상적인 환경, 정상 분비단백질의 과잉생산일수도 있다. 이 같은 $\mathrm{ER}$ stress에 대응하는 가장 기본적인 것은 $\mathrm{UPR}$ (unfolded protein response; 소포체스트레스응답)라고 총칭 되는 특정 단백질의 전사유도와 총 단백질의 번역 억제 system이다[2]. 이때에 ER lumen에서 UPR에 관여하는 단백질들 을 소포체샤페론(ER chaperone)이라고 하다. 세포 내 단백질 의 역동적인 변화를 지탱해주고 있는 세포 내 조절인자로서 chaperone이 크게 주목을 받았다. 반대로 chaperone이라고 하 는 개념이 나와서 종래에는 그다지 생각되지 않았던 기능과 그 분자의 실체가 주목됨에 따라, 역동적인 단백질의 변화상 태가 베일을 벗게 되었다고 생각된다. Chaperone은 새롭게 합성된 폴리펩다이드의 folding, 단백질이 기능을 발휘하는 세 포내 소기관 혹은 세포외로 수송, 올바른 구조를 획득한 단백 질만이 기능을 할 수 있는 장소로 수송하는 품질관리, 더욱이 misfolding된 단백질과 불필요하게 된 단백질의 분해 등, 단백

\section{*Corresponding author}

Tel : +82-42-580-8206, Fax : +82-42-586-4800

E-mail : oykwon@cnu.ac.kr

†These authors contributed equally to this work.
질이 태어나서 성숙하고 죽기까지 그의 일생에 걸쳐서 여러 가지 단백질의 이것저것을 보살펴주는 단백질이다[1]. 세포내 의 여러 가지 단백질의 기능발현을 위해서 없어서는 안 되는 중요성을 가지고 있다.

Cyclic nucleotide phosphodiesterases는 cyclic nucleotides cAMP (cyclic adenosine $3^{\prime}-5^{\prime}$-monophosphate) 혹은 cGMP (cyclic guanosine $3^{\prime}-5^{\prime}$-monophosphate)을 hydrolyze하는 능력을 가진 superfamily protein로서 잘 보존된 common catalytic domain을 가지며 $65 \%$ 이상의 상동성을 보인다. 이는 여 러 종류의 extracellular stimuli (e.g. hormones, neurotransmitters)을 전달하는 intracellular second messenger로서 필수적이며 세포의 적절한 반응이 가능하게 하는 기능을 가지 고 있다[4]. 그리고 유전자는 1993년에 처음 보고되었으며, 높 은 cAMP hydrolyze능력 $(\mathrm{Km} 0.03-0.45 \mu \mathrm{M})$ 을 보였다. 지금 까지 5종류의 isoform이 보고되고 있다[10]. 유전자발현은 leukemic $\mathrm{T}$ cell line Jurkat에서 강하며 promoter region에 cAMP response element를 공통적으로 가지고 있다, 발현이 확인된 조직은 airway epithelial cells, brain, heart, liver, pancreas, thyroid and skeletal muscle, spleen, testis, lymphoid tissue등이다[7]. 그러나 cAMP phosphodiesterase 7A1 (cAMP PDE7A1)의 정확한 생물학적 기능은 불분명하지만 CAMP PDE7A1의 저해제가 면역 및 염증치료제개발을 목표 로 연구되고 있다. 본 연구자는 갑상선세포에서 DTT에 의해 서 발현이 증가하는 유전자중의 하나로 CAMP PDE7A1을 보 고하였다[8]. 본 연구에서는 ER stress에 의해서 cAMP PDE7A1의 발현증가와 다른 소포체샤페론의 발현에 어떤 상 과성이 있는지를 규명함으로서 이 유전자발현 조절의 실마리 를 제공하려고 한다. 


\section{재료 및 방법}

Coon's modified F-12 배양액에 5\% calf serum, $1 \mathrm{mM}$ non-essential amino acid, TSH $(10 \mathrm{mU} / \mathrm{ml})$, insulin $(10 \mu$ $\mathrm{g} / \mathrm{ml})$, hydrocortisone $(0.4 \mathrm{ng} / \mathrm{ml})$, transferrin $(5 \mu \mathrm{g} / \mathrm{ml})$ 의 4 가지 호르몬 혼합체를 첨가하여 만든 배양액 $(4 \mathrm{H}$ 배양액)에 FRTL-5 세포주(Fisher rat thyroid)를 배양하였다. 새로운 배양 액을 2-3일마다 교환하였고, 세포를 5-7일마다 계대 배양하였 다[6]. ER lumen의 $\mathrm{Ca}^{2+}$ 농도를 교란하는 calcium ionophore A23187 (1 $\mu \mathrm{g} / 5$ 시간, SERCA를 inactivation시키는 thapsigargin ( $5 \mathrm{uM} / 5$ 시간), 분비단백질의 ER에서 Golgi complex로 의 이동 방해하는 BFA $(10 \mu \mathrm{g} / \mathrm{ml})$, 신생단백질의 N-glycosylation inhibition하는 tunicamycin $(2 \mu \mathrm{g} / \mathrm{ml})$, 신생단백질의 -S-S-형성을 방해하는 DTT $(3 \mathrm{mM} / 3$ 시간)를 정상 배양세포에 처리한다[3]. RNA을 얻을 때에는 cold PBS로 충분히 세정한 다음에 사용한다. RNA isolation reagent (TRI-REAGENT)를 $500 \mu \mathrm{l}$ 넣고 2-3분 지난 후 scrapper로 긁어모아 $1.5 \mathrm{ml}$ tube에 넣고 $100 \mu \mathrm{l}$ 의 chloroform을 첨가하여 충분히 섞어준 다음 $13,000 \mathrm{rpm}, 4^{\circ} \mathrm{C}$ 에서 15 분 동안 원심 분리하였다. 약 $500 \mu \mathrm{l}$ 의 상등액을 취하여 새로운 tube로 옮기고 동량의 isopropanol 넣고 상온에서 10 분 정도 처리한 후 $13,000 \mathrm{rpm}$ 으로 10 분 동안 원심분리하고 tube의 바닥에 얻어진 pellet에 $75 \%$ ethanol을 초기 RNA isolation reagent 양과 동일한 $500 \mu \mathrm{l}$ 넣고 12,000 $\mathrm{rpm}$ 으로 5 분 동안 원심 분리하여 최종적으로 total RNA를 얻었다. DEPC가 처리된 증류수에 녹여 UV spectrophotometer로 정량하였다. 그 다음으로 수행한 RT-PCR은 RNA $(3 \mu \mathrm{g})$ 를 $80^{\circ} \mathrm{C}$ 에서 3 분 가열하여 denaturation 시킨 후 바로 얼음에 담가둔다. 10X buffer $3 \mu \mathrm{l}, \mathrm{dNTP} 4 \mu \mathrm{l}, 1 \mu \mathrm{l}$ 의 oligo-dT (300 ng), 10,000 U의 역전사효소와 RNase inhibitor를 첨가하 고 총 $30 \mu \mathrm{l}$ 가 되게 한 후 $42^{\circ} \mathrm{C}$ 에서 1 시간 30 분 간 반응시켜 cDNA를 합성한다. 반응이 끝난 후 $94^{\circ} \mathrm{C}$ 에서 2 분 반응시켜 역전사효소를 inactivation시킨 다음 최종 $100 \mu 1$ 로 맞춘다. 그 다음 단계로 $\mathrm{cDNA}$ 를 증폭하기 위해서 $\mathrm{PCR}$ 을 수행하였다. PCR 반응액 $20 \mu 1$ 에 각각의 Forward 와 Reverse primer를 넣어서 $94^{\circ} \mathrm{C} 5$ 분, $94^{\circ} \mathrm{C} 30$ 분, $57^{\circ} \mathrm{C} 40$ 초, $72^{\circ} \mathrm{C} 40$ 초로 27 회 반복 하여 전기영동으로 확인하였다. 사용된 Forward 와 Reverse primer는 아래와 같다. F (5'-AGCTGAGTCTCTGCCTTTCG $\left.-3^{\prime}\right)$, and R ( $5^{\prime}$-TGTGGTCTCTACCTCCCTGG-3') for Chop; F (5'-CGTTCAGACAGAGGCCAGTTC-3'), and R (5'-CGA GGACCACCATCATCC-3') for Rpn1; F (5'-CAGAGTTCTGC CACCGCTTC- $\left.{ }^{\prime}\right)$, and R (5'-TCCTCGAGATCGTCATCATC3') for PDI; F (5'-ATCCCAGTGTCTGATGATGCGGAA-3'), and R (5'-CTCTCCTGGACTGGCTGATATC-3') for Tg; F (5'-ACCACCAGTCCATCGCCATT-3') and R (5'-CCACCCT GGACGGAAGTTTG-3') for IRE1; F (5'-AGTG GTGGCCA CTAATGGAG- $\left.{ }^{\prime}\right)$ and R (5'-TCTTTTGTCAGG GGTCGTTC-
3') for Bip; F (5'-CTAGGCCTGGAGGCCAGG TT-3') and R (5'-ACCCTGGAGTATGCGGGTTT-3') for ATF6; F (5'-GGT CTGGTTCCTTGGTTTCA-3') and R (5'-TTCGCTGGCTGTG TAACTTG-3') for PERK; F (5'-AAACAGAGTAGCAGCTCA GACTGC- $\left.3^{\prime}\right)$ and R (5'-TCCTTCTGGGTAGACCTCTGGGA G-3') for XBP1; F (5'-GGACTGGGACGAAGAGATGG-3') and R (5'-CCTCTGCTCCTCATCCTGCT-3') for cAMP phosphodiesterase 7A1; F (5'-AGCCATGTACGTAGC CATCC-3') and $\mathrm{R}$ ( $5^{\prime}$-CTCTCAGCTGTGGTGGTGAA- $\left.3^{\prime}\right)$ for GAPDH.

\section{결과 및 고찰}

cAMP PDE7A1의 유전자발현이 각종 ER stress inducible drug (tunicamycin, A23187, DTT, BFA)에 반응하는지는 알기 위하여, tunicamycin을 처리하여 당단백질의 N-glycosylation 을 저해하여 ER lumen에 misfolded protein 축적을 유도, A23187을 처리하여 ER lumen내의 칼슘교란을 유도, DTT를 처리하여 ER lumen 내의 단백질 folding과정에서 -S-S- 형성 방해를 유도, $\mathrm{BFA}$ 를 처리하여 분비단백질이 $\mathrm{ER}$ 에서 Golgi complex로의 이동을 저해를 하였다. Fig. $1 \mathrm{~A}$ 에서 각각의 ER stress 유도제에 의해서 ER chaperone (Bip, ERp29, Canx, $\mathrm{hPDI}$ ), ER stress sensor (PERK, ATF6, Ire1)와 전사인자인 Chop의 발현이 모두 상승하였다, 특히 다른 것의 발현에 비하 여 cAMP PDE7A1의 발현이 상승하였다. RpnI의 발현변화가 없는 것으로 보아 ER자체의 크기변화는 없는 것으로 추측되 지만, 분비 당단백질인 $\mathrm{Tg}$ 의 발현은 저하되는 것을 보여 세포 가 적절한 ER stress 상태임을 알 수 있다. 이 결과는 cAMP $\mathrm{PDE7A1}$ 의 유전자발현이 UPR에 관여하는 인자들보다가 ER stress에 더욱 강하게 발현하는 것이다. Fig. $1 \mathrm{~B}$ 는 칼슘이 cAMP PDE7A1 유전자발현에 미치는 영향을 알기 위하여 단 순하게 ER lumen내의 칼슘교란을 유도하는 A23187과 intracellular $\mathrm{Ca}^{2+}$ pump (SERCA; sarco/endoplasmic reticulum $\mathrm{Ca}^{2+}$-ATPase)에 직접 결합하여 칼슘교란을 유도하는 thapsigagin을 처리하여 비교 실험하였다. A23187과 thapsigagin을 각각 5시간 처리한 다음에 배지에서 각각을 제거한 후에 cAMP PDE7A1 유전자발현을 조사하였다. A23187를 제거한 다음에는 발현의 변화가 없이 계속 상승발현이 유지되지만 thapsigagin의 경우는 발현이 현저하게 저하되었다. 이는 세포 배양액속의 A23187의 제거로 세포가 원래상태로 돌아오지만 thapsigagin에 의해서는 일단 불활성화된 SERCA는 기능을 상실하여 원래상태로 되돌아오지않기 때문인 것으로 생각된 다. Fig. 1C는 TSH가 ER stress 조건에서 cAMP PDE7A1 유전 자발현에 미치는 영향을 실험한 결과이다. TSH만 처리할 경 우는 발현이 조금 내려가지만 tunicamycin에 의한 ER stress 를 유도에는 방해를 하지 않는다. 그러나 A23187에 의한 ER stress 유도때에는 발현이 많이 방해를 받는다. 이는 세포 내 
A

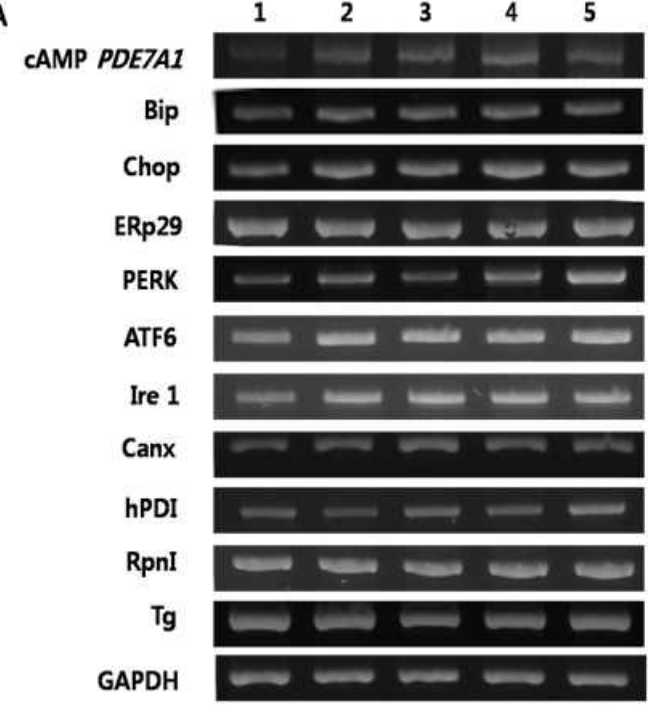

1.Control, 2.Tunicamycin, 3.A23187, 4.DTT, 5.BFA
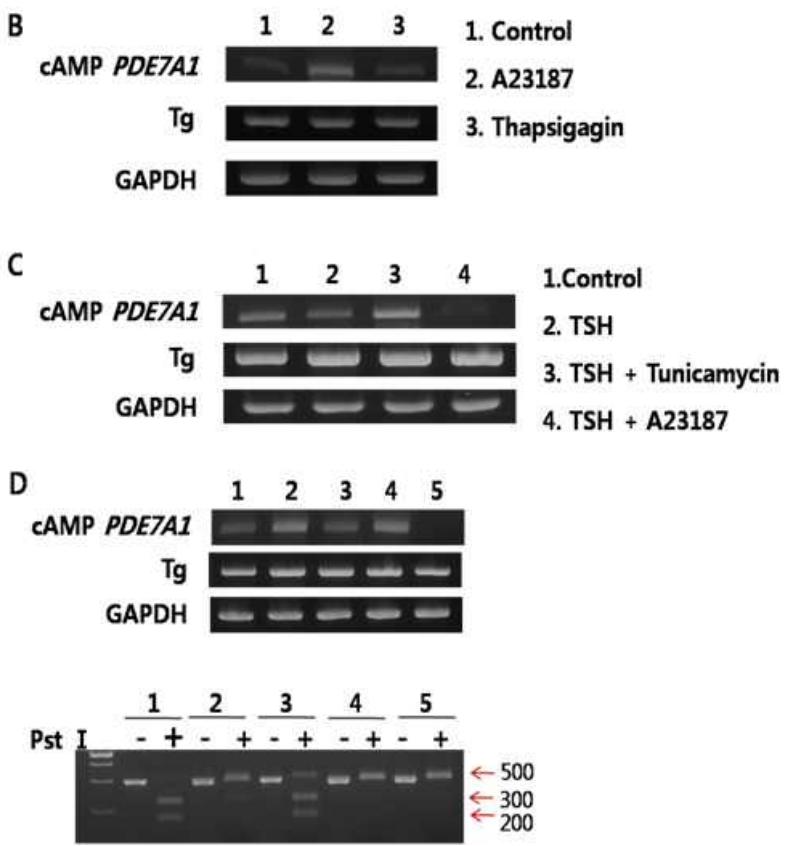

Fig. 1. Expression of cAMP phosphodiesterase 7A1 (cAMP PDE7A1) gene by endoplasmic reticulum (ER) stresses. FRTL-5 cells were treated with various ER stress inducible drugs during indicated time. All mRNA levels of immunoglobulin heavy chain binding protein (BiP), CCAAT/enhancer binding protein (C/EBP) homologous protein (Chop), endoplasmic reticulum protein 29 (ERp29), protein kinase RNA-like endoplasmic reticulum kinase (PERK), activating transcription factor 6 (ATF6), inositol-requiring 1 (Ire1), calnexin (CANX), human protein disulfide isomerase (hPDI), ribophorin I (Rpn1) as ER stress landmarks, thyroglobulin (Tg) as a secretory protein, and cAMP phosphodiesterase 7A1 (cAMP PDE7A1) as a target were measured by semiquantitative RT-PCR after treatment of various ER stresses. All experiments were performed at least three times in the same conditions. (A) Expression of genes (cAMP PDE7A1, ER chaperones, ER stress sensors) by various ER stress inducible drugs. (B) Effects of calcium on the expression of cAMP PDE7A1. (C) Effects of TSH on the expression of cAMP PDE7A1. (D) IRE1a-dependent splicing of mXBP1. cDNA of mXBP1 was isolated by PCR, and the amplified mXBP1 cDNA fragment were digested with Pst.

칼슘교란상태에서 TSH에 의해서 CAMP PDE7A1 유전자발현 이 강하게 억제되는 새로운 결과를 얻었다. ER stress 유도를 하기 위하여 범용되는 XBP1 digestion 실험으로 간접적으로 ER stress sensor와 그 이후의 인자에 미치는 영향을 실험하였 다[5]. Fig. 1D의 아래 panel에서 보이는 $500 \mathrm{bp}$ 밴드의 강약이 ER stress를 받는 강약과 비례한다. ER stress 유도제처리에 의해서 분절되지않은 $500 \mathrm{bp}$ 밴드가 control에 비하여 강하게 나타난다. 그중에서도 DTT와 BFA를 사용하였을 경우에 아주 강한 $500 \mathrm{bp}$ 밴드가 확인되었다. 이는 Fig. $1 \mathrm{~A}$ 에서는 ER stress 에 비슷한 발현을 보인 cAMP PDE7A1 유전자발현이 하부신 호전달계로 가면서 분비단백질의 구조결함과 이동저해에 의 한 ER stress가 강하게 전달되는것을 의미한다.

UPR은 ER에 un/misfolded protein들이 ER 밖으로 분비되 지 못하여 정상적인 생리상태보다 과량 축적되었을 때 $\mathrm{ER}$ chaperone의 발현 증가, 단백질번역 억제, 불량한 단백질의 제거 등을 통한 분비단백질의 ER quality control (ERQC, 소포 체품질관리)을 담당한다. UPR이 ER stress에 대응하는 세포의 항상성 조절에 실패하는 상황이 초래하면 염증 및 apoptosis
가 유도된다. UPR이 세포의 보호와 사멸이라는 두 가지 상반 된 기능을 담당하는 유전자들을 모두 발현시킨다는 것은, 이 들 사이의 균형을 조절 및 유지하는 기전이 존재한다는 것을 의미한다. 특히, 이 조절 기전에서 ER stress에서 발현이 조절 되는 cAMP PDE7A1이 어떤 역할을 하는지를 밝히는 것이 연구의 최종목표이다. 본 연구에서는 ER stress의해서 세포내 2차 신호전달체중의 하나인 CAMP PDE7A1 유전자의 발현이 조절되는지를 확인하여, 장래에 ER stress에 의한 세포의 생사 조절에 cAMP PDE7A1이 어떻게 관련하는지를 밝히려고 한 다. 이는 세포에 direct signal을 세포 내에서 어떻게 선택적으 로 positive 혹은 negative하게 조절하는 기능으로 전환하는지 를 이해할 수 있는 기회를 제공한다.

\section{감사의 글}

이 연구는 2010년도 충남대학교 학술연구비에 의해 지원되 었음. 


\section{References}

1. Braakman, I. and N. J. Bulleid. 2011. Protein folding and modification in the mammalian endoplasmic reticulum. Annu. Rev. Biochem 80, 71-99.

2. Chakrabarti, A., A. W. Chen, and J. D. Varner. 2011. A review of the mammalian unfolded protein response. Biotechnol. Bioeng. 108, 2777-2793.

3. Goo, T. W., E. Y. Yun, J. S. Hwang, S. W. Kang, S. Park, K. H. You, and O. Y. Kwon. 2002. Molecular characterization of a Bombyx mori protein disulfide isomerase (bPDI). Cell Stress Chaperones 7, 118-125.

4. Han, P., P. Sonati, C. Rubin, and T. Michaeli. 2006. PDE7A1, a cAMP-specific phosphodiesterase, inhibits cAMP-dependent protein kinase by a direct interaction with C. J. Biol. Chem 281, 15050-15057.

5. Kwon, K., T. W. Goo, and O. Y. Kwon. 2005. Development of rapid detection method for unfolded protein response in the mammalian cells. J. Exp. Biomed Sci. 11, 249-252.
6. Kwon, O. Y., Y. J. Kim, Y. Choi, H. Kim, C. Song, and M. Shong. 1999. The endoplasmic reticulum chaperone GRP94 is induced in the thyrocytes by cadmium. $Z$. Naturforsch $C$. 54, 573-577.

7. Miró, X., S. Pérez-Torres, J. M. Palacios, P. Puigdomènech, and G. Mengod. 2001. Differential distribution of cAMP-specific phosphodiesterase 7A mRNA in rat brain and peripheral organs. Synapse 40, 201-214.

8. Park, S., I. Hwang, M. Shong, and O. Y. Kwon. 2003. Identification of genes in thyrocytes regulated by unfolded protein response by using disulfide bond reducing agent of dithiothreitol. J. Endocrinol. Invest. 26, 132-137.

9. Rutkowski, D. T. and R. J. Kaufman. 2004. A trip to the ER: coping with stress. Trends Cell Biol. 14, 20-28.

10. Wang, P., P. Wu, R. W. Egan, and M. M. Billah. 2000. Cloning, characterization, and tissue distribution of mouse phosphodiesterase 7A1. Biochem Biophys. Res. Commun. 276, 1271-1277.

\section{초록 : 소포체스트레스에 의한 CAMP phosphodiesterase 7A1 유전자의 발현}

권기상 ${ }^{1}$ 권영숙 ${ }^{2}$ 권오유 *

('충남대학교 의학전문대학원 해부학교실, ${ }^{2}$ 중부대학교 간호학과)

갑상선 배양세포(FRTL5)에서 ER stress에 의해서 ER chaperone (Bip, ERp29, Calnexin and PDI), ER stress sensor (PERK, ATF6 and Ire1)와 cAMP phosphodiesterase 7A1 (cAMP PDE7A1) 유전자발현이 증가하는 것을 알았다. 세포배양배지에서 A23187을 제거하면 CAMP PDE7A1 유전자발현이 회복되지만, thapsigagin의 경우는 회복되지 않았다. 그리고 A23187과 TSH를 함께 처리한 경우는 아주 강하게 CAMP PDE7A1 유전자의 발현이 억제되었다. 이 같은 결과는 ER stress에 의해서 cAMP PDE7A1 유전자발현이 상승 발현된다는 첫 보고이다. 